
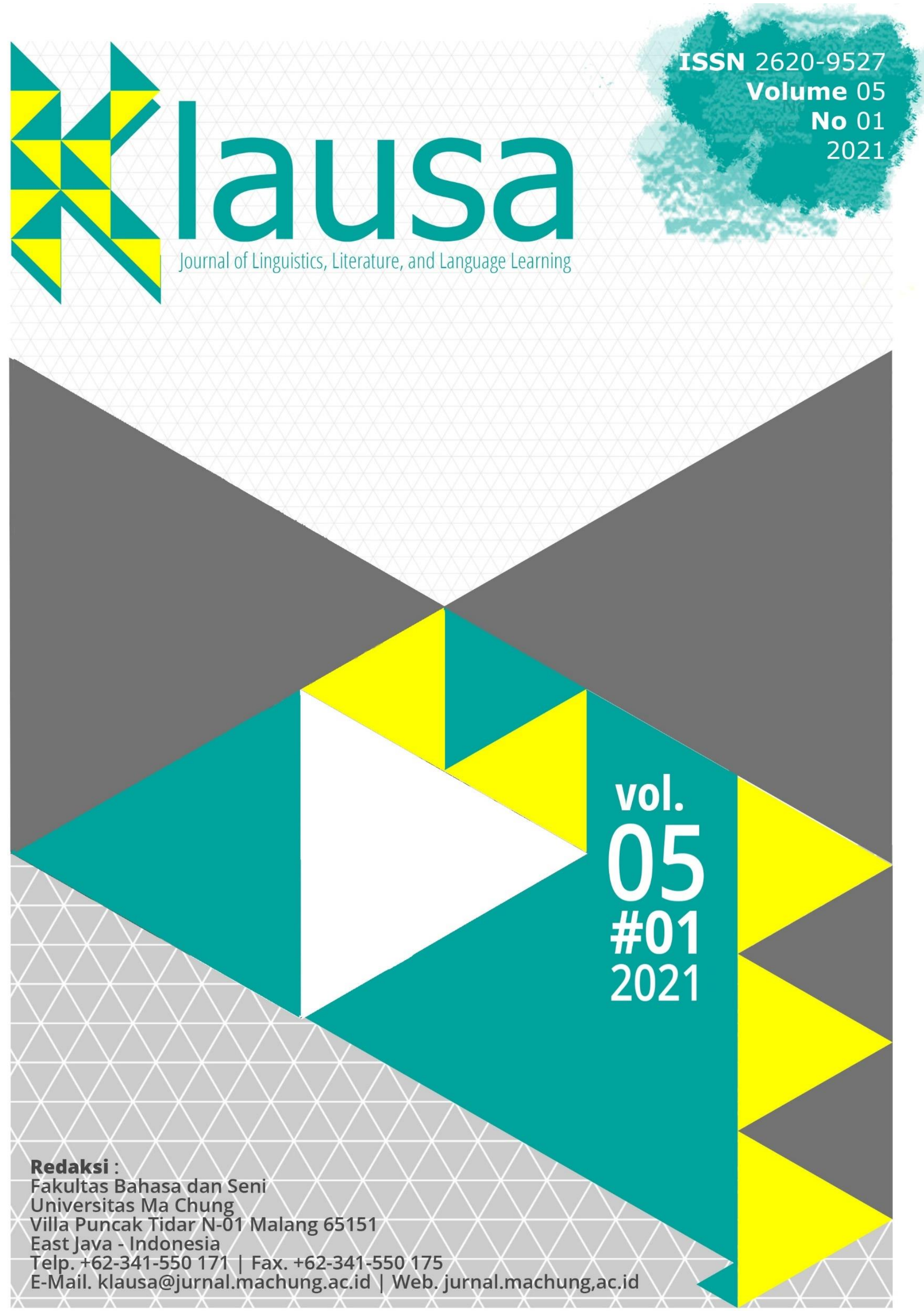
ISSN: $\quad 2301-4822(p)$

DOI: $\quad$ 10.33479/klausa.v4i02

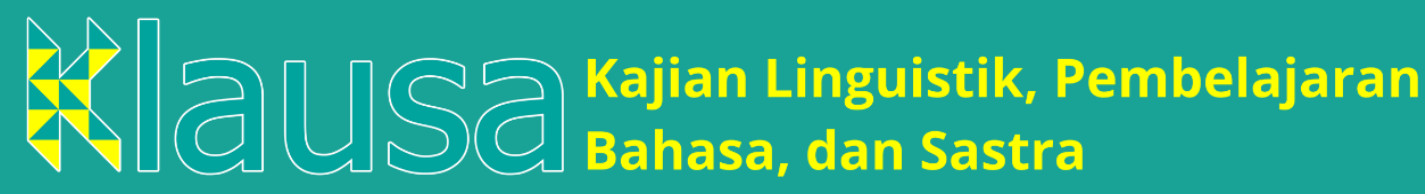

\section{Editorial Team}

$\begin{array}{ll}\text { Editor-in-Chief } & : \text { Dr. Daniel Ginting } \\ \text { Journal Manager } & : \text { Wawan Eko Yulianto, Ph.D. } \\ \text { Editors } & \text { Prof. Dr. Patrisius I. Djiwandono } \\ & \text { Lilis Lestari Wilujeng, M.Hum. } \\ \text { Reviewers } & \text { F.X Dono Sunardi, M.A. } \\ & \text { Dhatu Sitaresmi, MTCSOL. } \\ & \text { Anggrah Diah Arlinda, MTCSOL. } \\ & \text { Yohanna Nirmalasari, S.Pd., M.Pd. } \\ & \text { Prof. A. Effendi Kadarisman, Ph.D. } \\ & \text { Sisilia Halim, Ph.D. } \\ & \text { Dr. Mundi Rahayu } \\ & \text { Dr. Ross Wood } \\ & \text { Dr. Leticia Araceli Salas Serrano } \\ & \text { Faculty of Language and Arts } \\ & \text { Universitsas Ma Chung } \\ \text { Frequency } & \text { The Faculty of Language and Arts } \\ \text { Mublisher } & \text { Ma Chung University } \\ & \text { Villa Puncak Tidar N-01 (65151) } \\ & \text { Malang, East Java, Indonesia } \\ & \text { Email: jurnal.klausa@machung.ac.id } \\ & \text { Twice a year } \\ \text { Address } & \end{array}$




\section{CONTENTS}

FOREWORD

iii

MANAGEMENT OF POLITENESS STRATEGIES AND RHETORICAL DEVICES IN DONALD TRUMP'S SPEECHES DURING THE CONFLICT WITH IRAN: PRAGMATIC VIEW

Khoirun Nisak, Lisetyo Ariyanti

PERBANDINGAN UNSUR PEMBANGUN CERITA NOVEL DAN FILM SANG PEMIMPI

Muhamad Deni Setiawan. 19

HALF-CASTE'S STATE OF LIMBO IN KATHARINE SUSANNAH PRICHARD'S “MARLENE” AND “FLIGHT” (1967)

Laily Ramadhani, Mamik Tri Wedawati. 29

ANALISIS KUALITAS TERJEMAHAN TEKS BAHASA JEPANG KE BAHASA INDONESIA DENGAN BING TRANSLATOR

Wisnu Setya Budi, Febi Ariani Saragih 45

印尼玛中大学汉语学习者词汇学习策略调查研究

Vincentius Valiandy Jiuangga,S.Kom.,MTCSOL 63 


\title{
MANAGEMENT OF POLITENESS STRATEGIES AND RHETORICAL DEVICES IN DONALD TRUMP'S SPEECHES DURING THE CONFLICT WITH IRAN: PRAGMATIC VIEW
}

\author{
Khoirun Nisak ${ }^{1}$, Lisetyo Ariyanti ${ }^{2}$ \\ ${ }^{1}$ Universitas Negeri Surabaya, khoirunnisak98@yahoo.com \\ Universitas Negeri Surabaya, lisetyoariyanti@unesa.ac.id
}

\begin{abstract}
The research aims to figure out the use of politeness strategies and rhetorical devices used by Trump and attempt to reveal the behavior and purpose behind the speeches delivered by Donald Trump during the conflict with Iran taken by the videos in The White House channel on YouTube which are published on January $4^{\text {th }}$ and $9^{\text {th }}, 2020$. This study employs a descriptive qualitative method by involving the theories by (Brown \& Levinson, 1987), (Jowett \& O'Donnell, 2012), (G., Preminger, \& Brogan, 1994), and Wodak (1987). This study found that Donald Trump mostly uses positive politeness to attend his audience's attraction to reach his goals and based on the data of the occurance of rhetorical devices, Donald Trump mostly uses Ethos in persuasion which means he frequently shows his good characteristic to reveal people's trust and followed by using manipulation in each of his in order to manipulate people for achieving his purposes.
\end{abstract}

Key Terms: politeness strategies, rhetorical devices, donald trump, pragmatic

\section{INTRODUCTION}

The United States and Iran have been at odds since a long time ago. These two countries have been retaining a cold war to each other which it becomes a common phenomenon to the world. Even after the tragedy of 9/11 attacks, Iran secretly helped the US to defeat the Taliban, a corporate of both countries, but the $43^{\text {rd }}$ president of the United States, George Bush, had a speech in a State of Union address in 2002 and he defined Iran as part of an "Axis of Evil" and it provoked anger in Iran. Though there was finally a big breakthrough obtained for the US and Iran in 2013 by signing an Iran nuclear deal's after years of negotiation with the administration of the $44^{\text {th }}$ president of the United States, Barack Obama, and other six nations which finally slowed Iran's nuclear development program. 
But it became in fire again when Donald Trump, the $45^{\text {th }}$ president of the United States declared in his inauguration that the United States would ban nationals from seven Muslim-majority nations, including Iran, from entering the United States. Iran then was offended by his speech and considered that as an insult. Moreover, Trump fulfilled a campaign promise and declared that the United States quit the Iran nuclear deal. The political speeches deliverd by either the president or the important leaders of these two countries brought huge impacts to the world, especially these two involved countries.

Political affairs have huge impacts on a country. Since the government takes over most of the country's stuff, the leaders and governors must have an ability to carry the country very well. Furthermore, political speeches play an important and essential role to the politicians as they desire to achieve their purpose by delivering the speech. There is always an intention in every speech delivered by the politician as they can manipulate and persuade people as it means to disseminate or promote particular ideas (Jowett \& O’Donnell, 2012).

During the conflict with Iran, Donald Trump, the $45^{\text {th }}$ president of the United States, has delivered plenty of speeches which affected many of things. To reveal the intention and messages behind the speeches, Yule (2010) mentions pragmatics is the best study to use as the definition of pragmatics itself is the study which concerns about communication delivered by a speaker or writer and interpreted by a listener or reader. Two most important subjects of pragmatic which can be used to analyze political speeches are politeness strategies and rhetorical devices since they propose to figure out how politicians behave during giving a speech and reveal the message and purpose behind their speech.

This study will analyze the speeches of Donald Trump during the conflict with Iran taken by the videos in The White House channel on YouTube. This study aims to figure out the use of politeness strategies and rhetorical devices used by Trump and attempt to reveal the behavior and purpose behind the speeches delivered by Donald Trump. There are three research questions in this study: (1) What are the types of politeness strategies used by Donald Trump? (2) What are the rhetorical devices of those politeness strategies? (3) How do politeness strategies and rhetorical devices convey Trump's perspective on conflict with Iran?

\section{Politeness Strategies}

Based on Yule (2010), politeness is an attitude of the speaker's social behavior which shows awareness of another person's face. This study determines to analyze politeness strategies in order to identify how Donald Trump as a politician who delivers speeches behaves and mantains social relationship with audience to achieve his goals. The researcher employs a politeness strategies theory by (Brown \& Levinson, 1987) which is divided into four. 


\section{Bald-on Record}

Bald-on record is the most direct, clear, and unambiguous act strategy more than the others. Nasution \& Ariyanti (2015) notes the speaker usually does not minimize the threat to the hearer's face since bald-on record responses are often aggressive. Bald-on record is mostly used without further ado and just to the point since the speaker delivers their aim directly so the hearer will immediately understand it, for example when the speaker requests the hearer to do something such as "clean it up!", "hear me out", and etc.

\section{Positive Politeness}

To use positive politeness strategy, the speaker needs to minimize the threat to the hearer's positive face. It generally appeals to the hearer's self-esteem rather than their freedom since it is used to value the hearer and make them feel good about themselves. This strategy attempts to avoid a conflict and sometimes it includes statements of friendship, solidarity, compliments, and etc. Some examples of doing this strategy are, "let's send the message to them", "You deserve this peace", and any others which can rise the hearer's positive face.

\section{Negative Politeness}

Appealing to someone through negative politeness is respecting their personal space and not intruding on them which attempts to cause as little inconvenience as possible and apologizing if engaging which them are acts which represents negative politeness. Negative politeness strategies are oriented towards the hearer's negative face and emphasize avoidance of imposition on the hearer. For example, being negatively polite may be to ask someone if you may open a window, so as not to infringe on their desire to have it shut or to ask "It is not too much trouble, could you please open the window?." Therefore it is giving options. Negative politeness can even go as far as to not direct request something in fear of infringement, but rather to hint at your desire and hope the other person complies.

\section{Off-Record}

Off-record is the most indirect and polite than the other politeness strategies outlined by Brown and Levinson. Off record is avoiding responsibility for the FTA often by being indirect. It means to response to a face-threatening act is to not response to it at all. This may mean completely ignoring the comment, or to comply with what the facethreatening act instructed someone to do. This strategy uses indirect language and removes the speaker from the potential to be imposing. For example, a speaker is using the indirect strategy might merely say "wow, it is getting cold in here" insinuating that it would be nice if the hearer would get up and turn up the thermostat without directly asking the hearer to do so. 


\section{Rhetorical Devices}

Rhetorical devices are the tools to persuade and convince people and mostly used in political speeches to persuade people, as the main aim of politician is to convince people so they will get people's trusts and achieve their goals. Rhetorical devices are classified into some branches, there are:

\section{Persuasion}

(Jowett \& O'Donnell, 2012) states that interactive process within a sender and receiver which is linked by symbols, verbal and nonverbal through which the persuader attempts to influence the audience's belief, behavior, and attitude. Persuasion itself demands into three appeals:

1. Ethos, derived from Greek word which means ethics. It is essential to any attempt to persuade because it reveals to character. Moreover, ehos can be seen as an attempt to create credibility which reveals to people's trust. Ethos represents character and credibility.

2. Logos, derived from Greek word which means logic or reason. It is a feature to the use of facts, statistics, figures, hard evidence, and so on. Logos represents logic, fact, and reason.

3. Pathos, derived from Greek word which means feeling. It is a feature to share values and emotions as it reveals to people's heart, sympathy, love, and compassion. Pathos represents sharing values and emotions.

\section{Amplification}

Amplification is one of rhetorical devices which is used to embellish a statement or sentence by adding further information. In speech, especially political speech, amplification performs the emphasis of the speaker's intention. The speakers repeat something that they already said which the purpose is to emphasize their aims. Not only repeating the words or phrases, the speakers sometimes add more information and details in order to highlight the importance of their idea. It also highlights the persuasive aspects of an idea by elaborating and emphasizing the reason why it needs to be considered as well as it increases the rhetorical effect and adds an overstatement.

\section{Repetition}

As a rhetorical device, repetition has been used by politicians to get the audience attention as it intends to emphasize the speaker's purposes and achieve clarification, confirmation, and effectiveness. The researcher elects some of the repetition types which are used the most by politicians in their speech:

1. Anaphora, which is the repetition of the same words or phrases which reinforces the meaning of words and arranges sentences in a similar way. 
2. Polysyndeton, which means the use of conjunctions to link a sequence of words, phrases, and sentences. Some politicians employ this strategy to emphasize a particular item to represent the flow and continuity (G., Preminger, \& Brogan, 1994).

\section{Manipulation}

Wodak (1987) mentions that manipulation is a form of persuasion. Moreover, in political speech, it is the most important thing to use as the main purpose of delivering a speech is to persuade the audience. Eloquence is also the best weapon for politicians while delivering a speech to attract the audience's attention. There are many ways of what politicians do in order to manipulate people and achieve their intention while giving a speech in public.

\section{RESEARCH METHOD}

The object of this study is Donald Trump which is the $45^{\text {th }}$ president of the United States who delivers two speeches to give a remark to Iran during the conflict. The videos were uploaded on January $4^{\text {th }}$ and $9^{\text {th }}, 2020$ in The White House channel on YouTube with a duration of each is 4 minutes and 16 minutes and 9 minutes and 17 minutes. There are ten utterances in total which each of the speeches has five utterances selected as they have the elements of politeness strategies and rhetorical devices to be analyzed. In this study, the researcher uses a descriptive qualitative method with two approaches in order to get a specific result, there are politeness strategies and rhetorical devices.

There are five techniques for gathering data based on Litosseliti, (2010) in her book entitled Research Method in Linguistics, those are: observation which consists of two types, the first one is participatory and the second one is non-participatory. Interview which also has two types, structure and non-structure. Questionnaire which is branched into two, open and close. The fourth one is test. And the last one is documentation. This study requires two techniques out of those five techniques to gather the data, there are nonparticipatory observation and documentation to collect the data since they are taken from the YouTube videos and the utterances delivered by Donald Trump.

This study employs different aspects to answer each of the research questions and get the data which are related to the research questions. The variety of the aspects will help the researcher to find out the relevant data related to the research questions. The information of the connection between research questions, data collection techniques, and aspects of data involved to answer each of the research questions are provided in Table 1. 
Table 1. The variety of the aspects to get the relevant data related to the research questions

\begin{tabular}{|l|l|l|l|}
\hline $\begin{array}{l}\text { Research } \\
\text { Questions }\end{array}$ & $\begin{array}{l}\text { Theories for } \\
\text { Analysis }\end{array}$ & $\begin{array}{l}\text { Data Collection } \\
\text { Techniques }\end{array}$ & $\begin{array}{l}\text { Specific } \\
\text { Aspects }\end{array}$ \\
\hline $\begin{array}{l}\text { RQ-1 } \\
\text { What are the types } \\
\text { of politeness } \\
\text { strategies used by } \\
\text { Donald Trump? }\end{array}$ & $\begin{array}{l}\text { (Brown \& Penelope, } \\
\text { 1987) }\end{array}$ & $\begin{array}{l}\text { 1. Non- } \\
\text { participatory } \\
\text { observation } \\
\text { 2. Documentation }\end{array}$ & $\begin{array}{l}\text { 1.Politeness } \\
\text { Strategies }\end{array}$ \\
\hline $\begin{array}{l}\text { RQ-2 } \\
\text { What are the } \\
\text { rhetorical devices } \\
\text { of those politeness } \\
\text { strategies? }\end{array}$ & $\begin{array}{l}\text { (Gowett \& O'Donnell, } \\
\text { (Godak, (1987) }\end{array}$ & $\begin{array}{l}\text { 1. Non- } \\
\text { participatory } \\
\text { observation } \\
\text { 2. Documentation }\end{array}$ & $\begin{array}{l}\text { 1.Rhetorical } \\
\text { Devices }\end{array}$ \\
\hline $\begin{array}{l}\text { RQ-3 } \\
\text { How do politeness } \\
\text { strategies and } \\
\text { rhetorical devices } \\
\text { convey Trump's } \\
\text { perspective on } \\
\text { conflict with Iran? }\end{array}$ & $\begin{array}{l}\text { (Brown \& Penelope, } \\
\text { (Jowett \& O'Donnell, } \\
\text { 2012) } \\
\text { (G. et al., 1994) } \\
\text { Wodak, (1987) }\end{array}$ & $\begin{array}{l}\text { 1. Non- } \\
\text { participatory } \\
\text { observation } \\
\text { 2. Documentation }\end{array}$ & $\begin{array}{l}\text { 1.Politeness } \\
\text { Strategies } \\
\text { Devices }\end{array}$ \\
\hline
\end{tabular}

The researcher is required to analyze after gathering and finding the relevant data by using data analysis technique according to (Miles, Huberman, \& Saldana, 2014), those are: data condensation, data display, and conclusion drawing/verification. First, the data need to be reduced to make the data simpler, which means only particular utterances which match to the theories of the research questions will be applied. To answer the first and second research question, data display will be employed since they require the use of each aspects. Conclusion data/ verification attempts to examine the validity of the data to make them more significant. The examples of data display to answer the first and second research question are drawn in Table 2 and 3.

Table 2. The example of analysis of the occurance of Politeness Strategies

\begin{tabular}{|l|l|}
\hline \multicolumn{1}{|c|}{ Politeness Strategies } & Frequency \\
\hline Bald-on Record & \\
\hline Positive Politeness & \\
\hline Negative Politeness & \\
\hline Off-Record & \\
\hline Total & \\
\hline
\end{tabular}


Table 3. The example of analysis of the occurance of Rhetorical Devices

\begin{tabular}{|l|l|l|l|l|l|l|}
\hline & \multicolumn{5}{|c|}{ Rhetorical Devices } \\
\hline \multirow{3}{*}{} & Persuasion & Frequency & Amplification & Repetition & Frequency & Manipulation \\
\cline { 2 - 7 } & Ethos & & & Polysyndeton & & \\
\cline { 2 - 7 } & Logos & & & Anaphora & & \\
\cline { 2 - 7 } & Pathos & & & & & \\
\hline Total & & & & & & \\
\hline
\end{tabular}

\section{FINDINGS AND DISCUSSION}

\section{A video by The White House channel on YouTube entitled "President Trump Delivers a Statement on Iran" published on January 4, 2020.}

Data A-1

"As President, my highest and most solemn duty is to defense our nation and its citizens".

1. Politeness Strategy

In this statement, President Trump uses positive politeness as he indirectly says his promise to defense the nation and its citizens. He indirectly promises his citizens that he will protect the country from any threat, as in the context of his speech is the conflict with Iran. He declares that statement in order to make all of Americans feel safe and lessen their worries.

2. Rhetorical Devices

a. Persuasion (Ethos)

The President Trump tries to convince his people to trust him because he will always defense his nation and the people. He wants to show his credibility with protecting the United States and declaring that to Iran to stop a war.

\section{b. Amplification}

The superlatives are used twice in President Trump's statement as he says "my highest and most solemn duty". He wants to emphasize his duty by saying the superlatives two times which means he holds the responsibilities tightly so that the audience will get his purpose which is to defense the United States and its citizens.

c. Repetition

The President Trump uses the repetition of Polysyndenton as he adheres a conjunction 'and' to emphasize his purpose "my highest and most solemn duty is to defense our nation and its citizens".

d. Manipulation 
The President Trump attempts to manipulate Iran to change their behavior towards using nuclear weapon by indirectly saying that he has the responsibility of protecting the United States which means that President Trump will never give up on Iran.

\section{Data A-2}

“Under my leadership, America's policy is unambiguous to terrorists who harm or intend to harm any American, we will find you, we will eliminate you, we will always protect our diplomats, service members, all Americans, and our allies".

\section{Politeness Strategy}

In this statement, President Trump uses bald on record as he directly warns and threatens the terrorists or any people who harm or intend to harm any American that they will be found and eliminated by the US government because President Trump will always protect the US diplomats, service members, people, and allies.

2. Rhetorical Devices

a. Persuasion (Ethos)

President Trump attempts to warn anyone who harms or intends to harm any American by clarifying that under his leadership, America's policy is unambiguous to terrorists. He emphasizes his responsible characteristic by saying "We will always protect our diplomats, service members, all Americans, and our allies".

\section{b. Amplification}

President Trump emphasizes his intention by inserting amplification in his speech as he says "America's policy is unambiguous to terrorists who harm or intend to harm any American". He mentions the word 'harm' twice which the second one here is more emphasizing his intention.

\section{c. Repetition}

The repetition of anaphora is used in this statement as the President Trump repeats the phrase 'I will' three times while saying "We will find you, we will eliminate you, we will always protect our diplomats, service members, all Americans, and our allies" to emphasize his promise.

\section{d. Manipulation}

Trump intends to warn the Iranian regime by manipulating ominous atmosphere in his speech by declaring his statement and promise to never let any terrorists destroy the US.

Data A-3

"We took an action last night to stop a war. We did not take action to start a war".

1. Politeness Strategy

8 | DOI: 10.33479/klausa.v5i1.395 
In this statement, President Trump uses a plural pronoun "we" as he explains to Iran that what the US did was to stop a war, not to start a war. One of the negative politeness aspects is to use plural pronouns.

2. Rhetorical Devices

a. Persuasion (Logos)

President Trump tries to explain his reason of doing an action last night was to stop a war. He asserts the reason to make the Iranian regime knows that the war between them needs to be ended.

\section{b. Repetition}

Trump uses the repetition of anaphora as he mentions a noun phrase 'a war' twice in his statement said "We took an action last night to stop a war. We did not take action to start a war". He emphasizes 'a war' in purpose to Iran to stop the war.

\section{c. Manipulation}

The statement which delivered by President Trump was made to manipulate Iran to bound a peace with the United States as he says he took an action last night to stop a war. The US no longer wants to have a war.

Data A-4

"The future belongs to the people of Iran-those who seek peaceful coexistence and cooperation-not the terrorists warlords who plunder their nation to finance bloodshed abroad".

\section{Politeness Strategy}

In this statement, President Trump uses positive politeness as he attends to Iran's interest by indirectly making a request to Iran to stop the terror so that they will have a future. President Trump considers that the terrorist warlords do not have a future and thus he attempts to influence the other of Iran people to have a future by seeking peaceful coexistence and cooperation rather than following their ruthless regime.

2. Rhetorical Devices

\section{a. Persuasion (Logos)}

President Trump tries to persuade Iran to make peace by saying "The future belongs to the people of Iran-those who seek peaceful coexistence and cooperationnot the terrorist warlords who plunder their nation to finance bloodshed abroad". He attempts to convince all the Iranians that if they seek peaceful coexistence and cooperation, they will have a bright future.

\section{b. Amplification}


The noun phrase 'the people of Iran' is emphasized by President Trump as he says "the people of Iran-those who seek peaceful coexistence and cooperation-not the terrorist warlords who plunder their nation to finance bloodshed abroad". Here, the President Trump seems to emphasize the characteristic of Iran people who will have a future by adding further explanations which are "those who seek peaceful coexistence and cooperation" and "not the terrorist warlords who plunder their nation to finance bloodshed abroad".

c. Repetition

The repetition of polysyndeton is used in this statement since the President Trumps uses some conjunctions 'and' and 'to' to emphasize his statement as he says "The future belongs to the people of Iran-those who seek peaceful coexistence and cooperation-not the terrorist warlords who plunder their nation to finance bloodshed abroad".

\section{d. Manipulation}

President Trump attempts to manipulate Iran by mentioning a future will belong to the people of Iran who are seeking peaceful and not the terrorist warlords. He indirectly wants Iran to stop a war by manipulating them in the statement declared by him.

Data A-5

"The United States has the best military by far, anywhere in the world. We have the best intelligence in the world. If Americans anywhere are threatened, we have all of those targets already fully identified, and I am ready and prepared to take whatever action is necessary. And that, in particular, refers to Iran".

1. Politeness Strategy

In this statement, President Trump uses bald on record as he directly points Iran if they threaten any Americans, the US government and him are ready and prepared to take whatever is necessary. There is no attempt to minimize the threat to Iran conveyed in this statement.

2. Rhetorical Devices

a. Persuasion (Ethos)

The statement claimed by President Trump seems to be showing the characteristic and credibility of Trump. He mentions that the United States has the best military and intelligence in the world. He also utters that if any Americans are threatened, he is ready and prepared to take whatever is necessary. In this statement, President Trump wants to show to people that with the characteristic and capability he has, he will be responsible for all of the affairs which are relevant to the United States. 


\section{b. Repetition}

This statement uses the repetition of anaphora as he repeats the phrases 'we have' and 'the best' in his statement said 'The United States has the best military by far, anywhere in the world. We have the best intelligence in the world. If Americans anywhere are threatened, we have all of those targets already fully identified, and I am ready and prepared to take whatever action is necessary. And that, in particular, refers to Iran". President Trump wants to emphasize that America has the best quality of everything as he warns anyone out there to never take a risk to destroy the United States.

c. Manipulation

Trump tries to create a manipulation to frighten the Iranian regime by mentioning that America has the best military and intelligence in the world and he is ready and prepared to take whatever action is necessary if his people are threatened. In the last of this statement, he also says "And that, in particular, refers to Iran" which is intended for Iran.

\section{B. A video by The White House channel on YouTube entitled "President Trump Delivers Remarks" published on January 9, 2020.}

Data $B-1$

"The American people should be extremely grateful and happy, no Americans were harmed in last night's attack by the Iranian regime. We suffered no casualties, all of our soldiers are safe, and only minimal damage was sustained at our military bases".

\section{Politeness Strategy}

In this statement, President Trump uses positive politeness as he attends his audience's needs by sharing gratefulness and happiness to all Americans and shares reasons of that by being safe in last night's attack by the Iranian regime and only minimal damage was sustained at military bases.

\section{Rhetorical Devices \\ a. Persuasion (Ethos)}

President Trump aims to show his characteristic to people that with the credibility he has from the United States citizens make him to be responsible and able to protect his people from the last night's attack delivered by the Iranian regime so that no one were harm and everyone was safe.

\section{b. Amplification}

Trump uses an amplification here as he tries to emphasize his purpose that the American people should be extremely grateful and happy, then he adds the reasons why as he says "No Americans were harmed in last night's attack by the Iranian regime. We 
suffered no casualties, all of our soldiers are safe, and only minimal damage was sustained at our military bases".

\section{c. Repetition}

The repetition of polysyndeton is used in this statement as the President Trump emphasizes his purpose by repeating the conjunction 'and' as he states "The American people should be extremely grateful and happy, no Americans were harmed in last night's attack by the Iranian regime. We suffered no casualties, all of our soldiers are safe, and only minimal damage was sustained at our military bases"

\section{d. Manipulation}

President Trump attempts to manipulate the tense atmosphere to be better and convince the American people to be unworried by saying the statement that no one was harm in last night's attack because of the US government and him were already prepared.

Data B-2

"At my direction, the United States military eliminated the world's top terrorist, Qasem Soleimani".

\section{Politeness Strategy}

In this statement, President Trump uses off record as he indirectly declares his achievement that under his leadership, the United States military has eliminated the world's top terrorist, Qasem Soleimani which is to warn the Iranian regime in a winding way to not take a risk to destroy the US anymore.

2. Rhetorical Devices

a. Persuasion (Pathos)

President Trumps attempts to evoke the emotional response of the audience by stating that at his direction, the United States military successfully eliminated the world's top terrorist, Qasem Soleimani.

\section{b. Manipulation}

Trump employs the statement that the United States military finally eliminated Qasem Soleimani at his direction to make the Iran afraid and stop the war.

\section{Data $B-3$}

“The civilized world must send a clear and unified message to the Iranian regime: Your campaign of terror, murder, mayhem will not be tolerated any longer. It will not be allowed to go forward".

1. Politeness Strategy 
In this statement, President Trump uses positive politeness as he invites the civilized world to send a clear and unified message to the Iranian regime to stop the terror. He sends a request to other nations by involving both speaker and hearer in the activity in order to make the Iranian regime stop the terror.

\section{Rhetorical Devices}

\section{a. Persuasion (Pathos)}

President Trump requires other countries to make a clear and unified message to Iran to stop their cruel behavior by saying "The civilized world must send a clear and unified message to the Iranian regime: Your campaign of terror, murder, mayhem will not be tolerated any longer. It will not be allowed to go forward". He raises the emotional response of the audience especially other countries as he invites them to deliver a message to Iran.

\section{b. Amplification}

President Trump uses an amplification in his statement as he says 'a clear and unified message' and he emphasizes the content of the message by adding information as he says "Your campaign of terror, murder, mayhem will not be tolerated any longer. It will not be allowed to go forward".

\section{c. Repetition}

The repetition of polysyndeton is used here to emphasize the purpose as President Trump employs the conjunctions 'and' and 'to' as he delivers the statement "The civilized world must send a clear and unified message to the Iranian regime: Your campaign of terror, murder, mayhem will not be tolerated any longer. It will not be allowed to go forward"

\section{d. Manipulation}

Trump wants to manipulate other countries to make Iran stop the terror by inviting them to send a message to the Iranian regime as he evokes "The civilized world must send a clear and unified message to the Iranian regime: Your campaign of terror, murder, mayhem will not be tolerated any longer. It will not be allowed to go forward".

\section{Data $B-4$}

"Over the last three years, under my leadership, our economy is stronger than ever before and America has achieved energy independence. These historic accomplishments changed our strategic priorities. These are accomplishments that nobody thought were possible".

1. Politeness Strategy 
In this statement, President Trump uses positive politeness as he gives gifts to the Americans by stating his accomplishments which nobody thought were possible. He presents his people as the reciprocal for trusting him during his duty.

2. Rhetorical Devices

a. Persuasion (Ethos)

To make people believe that he is such a great President, Trump reveals his accomplishments which changed the US strategic priorities. He aims to convince the audience of his characteristic and credibility by emphasizing the achievements he has made.

\section{b. Manipulation}

As a way of convincing the audience, President Trump shows his capability of achieving accomplishments that nobody thought were possible. He also intends to manipulate his enemy that under his leadership, the United States has evolved rapidly.

\section{Data $B-5$}

"Finally, to the people and leaders of Iran, we want you to have a future and a great future-one that you deserve, one of prosperity at home, and harmony with the nations of the world. The United States is ready to embrace peace with all who seek it".

1. Politeness Strategy

In this statement, since the audience of his public speech is not only the Americans but all around the world, including the Iranian people, President Trump uses positive politeness as he inivites Iranian people as his hearers to have a great future by seeking peace and harmony with the nations of the world.

2. Rhetorical Devices

a. Persuasion (Ethos)

President Trump persuades Iran to make peace with others so they will have a great future and shows his characteristic of peaceful and openness to any country by saying "The United States is ready to embrace peace with all who seek it".

\section{b. Amplification}

Trump uses an amplification by saying "a future and a great future" to emphasize his purpose that Iran will have a future, even a great future if they seek peace and harmony with the nations of the world.

\section{c. Repetition}

The repetition of polysyndeton is used in this statement to emphasize a purpose as the President Trump uses a conjunction 'and' while declaring "Finally, to the people and leaders of Iran, we want you to have a future and a great future-one that you 14 | DOI: 10.33479/klausa.v5i1.395 
deserve, one of prosperity at home, and harmony with the nations of the world. The United States is ready to embrace peace with all who seek it".

\section{d. Manipulation}

As a way of convincing Iran, President Trump says about having a great future if they seek peace and harmony with other nations. He also says that the United States is ready to embrace peace with all who seek it to manipulate Iran to stop the terror and war and start having peace with other countries around the world.

Those findings can be summarized into two divided tables which discuss about the occurrence of politeness strategies and rhetorical devices that will examine the behavior and purpose behind the speeches delivered by Donald Trump. The analysis of the occurance of politeness strategies is drawn in Table 4 below.

\section{Table 4. Analysis of the occurance of Politeness Strategies}

\begin{tabular}{|l|c|}
\hline Politeness Strategies & Frequency \\
\hline Bald-on Record & 2 data \\
\hline Positive Politeness & 6 data \\
\hline Negative Politeness & 1 data \\
\hline Off-Record & 1 data \\
\hline Total & 10 data \\
\hline
\end{tabular}

From the data above, Donald Trump mostly uses positive politeness more than the others which is consisting of six data, then followed by bald-on record which consists of two data, negative politeness and off-record with each of them consists of only one data.

Table 5. Analysis of the occurance of Rhetorical Devices

\begin{tabular}{|l|l|c|c|l|c|c|}
\hline & \multicolumn{7}{|c|}{ Rhetorical Devices } \\
\hline \multirow{3}{*}{} & Persuasion & Frequency & Amplification & Repetition & Frequency & Manipulation \\
\cline { 2 - 7 } & Ethos & 6 data & 6 data & Polysyndeton & 5 data & 10 data \\
\cline { 2 - 7 } & Logos & 2 data & & Anaphora & 3 data & \\
\cline { 2 - 7 } & Pathos & 2 data & & & & \\
\hline Total & & 10 data & 6 data & & data & 10 data \\
\hline
\end{tabular}

The table above shows that President Trump uses four of rhetorical devices, there are: persuasion, amplification, repetition, and manipulation. Donald Trump uses three types of persuasion, which he mostly uses is Ethos with six data involved, followed by Logos and Pathos with each of them has two data. The usage of amplification applied in his speeches is only six data. The repetition of Polysyndeton owns five data and Anaphora owns three data. The President Trump also employs manipulation in all of his speeches. 
Both of the tables above convey Donald Trump's perspective on conflict with Iran as in those two speeches, particularly in politeness strategies, Donald Trump mostly uses positive politeness to attend his audience's attraction since his main audience are not only Americans who were there witnessing his speeches in the stage, but all people around the world who watch and listen to his speeches, he invites the other nations around the world to force the Iranian regime stop the terror and make the Iranian people themselves have a great future by stopping the terror and start making peace and harmony with all nations in the whole world. Donald Trump also wants to make the American people feel safe in order to make them always give their trust on him as he declares that his highest and most solemn duty is to defense the United States and its citizens and he makes it true. President Trump some time uses bald-on record since he attempts to emphasize his major goal which is to warn Iran to stop the terror by using bald-on record without lessening the threat so that Iran will feel threatened.

Based on the data of the occurance of rhetorical devices, Donald Trump mostly uses Ethos in persuasion which means he frequently shows his good characteristic such as being responsible to his duty to reveal people's trust. He also employs six data in amplification in order to emphasize his intention and make it comprehensible by using repetition which consists of Polysyndeton with the total of five data and Anaphora with only three data. The data also shows that Donald Trump uses manipulation in each of his speeches as the function of political speech itself is to manipulate people for achieving the speaker (politician)'s goals as he purposes to make Iran stop the terror by warning them and inviting the other nations around the world to do so.

\section{CONCLUSION}

After collecting the findings and data, the researcher finds that Donald Trump mostly uses positive politeness more than the others which is consisting of six data as he wants to make the American people feel safe in order to make them always give their trust on him and invites the other nations around the world as well to force the Iranian regime stop the terror and make the Iranian people themselves have a great future by stopping the terror and start making peace and harmony with all nations in the whole world. Then followed by using bald-on record which consists of two data, negative politeness and off-record with each of them consists of only one data.

In rhetorical devices, Donald Trump uses three types of persuasion, which he mostly uses is Ethos with six data involved which means he frequently shows his good characteristic to reveal people's trust, then followed by Logos and Pathos with each of them has two data. The usage of amplification applied in his speeches is only six data in order to emphasize his intention and make it comprehensible by using the repetition of Polysyndeton which owns five data and Anaphora owns three data. The President Trump also employs manipulation in all of his speeches in order to manipulate people for achieving his purposes. 
In addition, this study is recommended for the next researchers who are interested in doing further researches in these scopes to use these findings as the starting points in conducting the research. By using the same theories as this study, the next researchers are suggested to use different data sources, in this case of political speech which is a formal discussion in any literary work. The researchers should consider how pragmatics, especially politeness strategies and rhetorical devices are necessary in doing discussions such as this study. 


\section{REFERENCES}

Brown, P., \& Penelope, S. C. L. (1987). Politeness: Some Universal in Language Usage. Cambridge University Press. https://doi.org/10.1515/lpp-2013-0005

G., E., Preminger, A., \& Brogan, T. V. F. (1994). The New Princeton Encyclopedia of Poetry and Poetics. Princeton University Press. https://doi.org/10.2307/605141

Jowett, G. S., \& O'Donnell, V. (2012). Propaganda and Persuasion sixth edition. SAGE Publications, Inc.

Litosseliti, L. (2010). Research Methods in Linguistics. London: Continuum.

Miles, M. B., Huberman, M. a, \& Saldana, J. (2014). Qualitative Data Analysis second edition. SAGE Publications, Inc. https://doi.org/January 11, 2016

Nasution, A. F., \& Ariyanti, L. (2015). The Usage of Face Threatening Act in Princess Diaries 1 and Princess Diaries 2: The Royal Engagement Movies. Surabaya: State University of Surabaya.

Wodak, R. (1987). Language, Power and Idiology Studies in Political Discourse. Amsterdam: John Benjamins Publishing Company. https://doi.org/10.1515/text.1.1987.7.4.377

Yule, G. (2010). The Study of Language fourth edition. Oxford University Press. https://doi.org/10.1007/s13398-014-0173-7.2 